Nord-Afrika viser vei for resten av den arabiske verden i drakampen omkring utvidelse av kvinners sivile rettigheter. En kombinasjon av interne forhold og eksternt press har muliggjort reformer innen familierett, og styrket kvinners statsborgerskap det siste tiåret.

\title{
Arabiske kvinners statsborgerskap
}


TEKST: Rania Maktabi

ARABISKE KVINNERS marginaliserte posisjon i politikk og samfunnsliv er teoretisert ${ }^{\mathrm{I}}$ og dokumentert i nedslående levekårsstatistikk. Fjorårets World Economic Forums Global Gender Gap Report viser eksempelvis hvor dårlig stilt arabiske kvinner er når I34 stater sammenlignes etter kriterier som økonomisk deltagelse, politisk makt, adgang til utdanning, helse og overlevelse: De arabiske emirater ligger best an på I03. plass, etterfulgt av Tunisia (I07), Libanon (II6), Syria (I24), Egypt (I25), Marokko (I27) og Saudi-Arabia (I29), mens Jemen ligger nederst. ${ }^{2}$

Dette dystre bildet kan nyanseres hvis faktorer av juridisk karakter tas med i regnestykket. Tar man utgangspunkt i kvinnevennlige reformer i statslovgivningen - som vanskelig lar seg måle, men som er av betydning for demokratiseringen av samfunnet - ville Marokko og Egypt toppet lista over arabiske stater der kvinners statsborgerskap er blitt betydelig styrket det siste tiåret.

Fram til årtusenskiftet hadde tunisiske kvinner de mest omfattende sivile rettigheter i den arabiske verden i kraft av familieretten fra I956. Tunisia var også det første arabiske landet som i I993 endret statsborgerskapslovgivningen slik at kvinner fikk betinget rett til å overføre sitt statsborgerskap til egne barn. Årtusenskiftet ble et tidsskille: Lovendringer styrket egyptiske og marokkanske kvinners sivile rettigheter innen familierett, statsborgerskaps- og kriminallovgivningen. Små eller ingen endringer skjedde i Syria, Libanon eller Jordan, til tross for sammenlignbare ytre og indre pressfaktorer for å endre kjønnede statslover.

Med tanke på at opprørene i den arabiske verden i 20II startet i Nord-Afrika - og nettopp i Tunisia - ser jeg i denne artikkelen på hva som ligger bak det markante regionale skillet mellom reformer i kvinners favør i to nordafrikanske stater (Marokko og Egypt) og to levantinske stater (Libanon og Syria) i perioden I997 til 2010. ${ }^{3}$ Jeg redegjør først for forholdet mellom arabiske kvinners sivile rettigheter og deres statsborgerskap. Deretter trekker jeg fram drivkrefter bak lovendringene, og drøfter regimers prioriteringer omkring kvinnevennlige reformer. Avslutningsvis reflekterer jeg over betydningen av kvinners utvidete sivile rettigheter for demokratiseringen av arabiske stater.

\section{Arabiske kvinners statsborgerskap}

Statsborgerskap antyder et formelt bindeledd mellom borger og stat, og omfatter sivile, politiske og sosiale rettigheter avhengig av type politisk regime og omfordelingspolitikken som utøves. ${ }^{4}$ Sivile rettigheter forbindes gjerne med borgernes beskyttelse mot vilkår- 
lig statsmakt og etablering av rettsstatsprinsipper som likhet for loven. Til tross for at likhet mellom kvinner og menn er nedfelt i konstitusjonen i de fleste arabiske stater har kvinner og menn ulike rettigheter i tre juridiske arenaer i statslovgivningen:

i) Innen familieretten - som regulerer ekteskap, skilsmisse, arv, adopsjon, økonomisk underhold av kvinner og barn ved skilsmisse - er myndige kvinner underlagt mannlig vergeskap (wilaya).

ii) I statsborgerskapslovgivningen har ikke kvinnelige borgere mulighet til å gi sitt statsborgerskap til barn hvis gift med ikke-borgere.

iii) Innen strafferett blir kvinnedrap (femicide) begått av mannlige slektninger enten benådet eller straffeutmålingen satt betydelig lavere (grovt sett noen måneder) enn manndrap (homicide) (grovt sett I5 år). Av disse tre domener utgjør familieretten det mest vidtrekkende sett med regler som så å si utruster mannlige og kvinnelige medlemmer av staten med ulike adgangskort.

Normgrunnlaget i familieretten tar utgangspunkt $i$ at kvinner er omsorgspersoner og menn er forsørgere, noe som gjør kvinnens juridiske status betinget av mannlige slektninger. Familieretten setter strenge krav for skilsmisse (for muslimske kvinner, og for begge kjønn innen kristen familierett); åpner opp for at umyndige jenter kan gifte seg; krever at kvinnen har verge for å inngå ekteskap; at vergen og / eller ektemannen samtykker i kvinnens yrkesvalg, utdanning, bosted og bevegelser i det offentlige rom; åpner opp for polygyni; ; og gir far og andre mannlige slektninger foreldrerett til barn ved skilsmisse.

En måte å se på arabiske kvinners begrensete og betingete statsborgerskap er å trekke linjene til kodifiseringen av religiøs rett som en del av statslovgivningen da statene ble selvstendige. Mens alle juridiske domener ble underlagt vestlige rettsprinsipper basert på rasjonalitet og positiv rett, forble familieretten underlagt religiøse lærdes og gruppers fortolkning og myndighet. Slik sett er statsmakten ikke sekularisert: religiøst-funderte prinsipper for ulikhet mellom kjønn er innbakt $i$ statslovgivningen. ${ }^{6}$

En annen måte å se kvinners betingete medlemskap er ut fra det gruppebaserte statsborgerskapet som både kvinner og menn er underlagt, og der religiøs tilhørighet er en

$$
\odot \odot \odot
$$

Kjønnede statslover medfører at kvinner ikke er fullverdige medlemmer av det politiske fellesskapet.

$\odot \odot \odot$

implisitt del av borgerens status som juridisk subjekt. Med andre ord: Som arabisk borger kan du godt være en mer eller mindre troende muslim, kristen eller jøde, men du kan ikke velge bort ditt medlemskap i en religiøs gruppe. Hovedgrunnen er at statsmakten må vite hvilken religion du tilhører for å avklare hvilken familierett du skal underlegges i saker og tvister av privatrettslig karakter. Suad Joseph formulerer det slik: «Family law may rightfully be said to be the most crucial site in which membership in religious communities has been a venue for constituting the Middle Eastern legal subject.» ${ }^{7}$ Dette er ikke unikt for arabiske stater. I alle stater som ikke har en sekularisert familierett er borgeren - frivillig eller ufrivillig - medlem av en religiøs gruppe. Dette gjelder nær en tredjedel av verdens stater (vi har I92 stater, ifølge FN) og inkluderer India, majoriteten av 57 medlemsstater i Den islamske konferanse, samt Israel - der auto- 
nomi for religiøse grupper er rettsliggiort i statsbyggingen.

Borgerens implisitte religiøse tilhørighet giør familieretten til et politisk spenningsfelt - og sågar en slagmark - for å definere, regulere og utøve styrke- og maktforhold mellom verdsligbasert og religiøst-baserte forordninger som skal ligge til grunn for borgernes rettigheter og plikter.

Kjønnede statslover medfører at arabiske kvinner ikke er fullverdige medlemmer av demos - det politiske fellesskap som utgjør «folket» - selv om de har politiske rettigheter. Ekskluderingen av kvinner fra statens politiske demos begrenser kvinners statsborgerskap og kompliserer demokratiseringen av arabiske stater på måter jeg reflekterer mer over avslutningsvis.

Siden 1990 har debatter omkring familieretten blitt politisert. ${ }^{8}$ Religiøse autoriteter ser sin eiendomsmakt over definisjonen og tolkning av familierettslige prinsipper truet av en rettighetsorientert internasjonal diskurs. Dette har mobilisert islamistiske grupper, så vel som ledere av religiøse minoriteter, til å motarbeide krav om reformer. Motstandere av kvinnevennlige reformer fremmer sammenlignbare argumenter i Egypt, Marokko, Libanon og Syria: likestilling mellom kjønn truer familien, er vestlig importerte verdier som ødelegger tradisjonelle og kulturelle normer, og medfører uønsket sekularisering av samfunnet. Til tross for betydelig motstand, har noen krav likevel munnet ut i lovendringer.

\section{Reformer som treffer kvinner 2000-20I0}

Fram mot årtusenskiftet levde arabiske kvinner under sammenlignbare sivilrettslige regimer. I løpet av tiåret 2000-20Io skjedde det endringer som Welchman betegner som en «tredje bølge» av reformer innen islamsk fam- ilierett. I den første fasen ble shariaregler og normer nedtegnet som ledd i utformingen av Den osmanske familieretten av I9I7, mens den andre fasen så kodifiseringen av hver stats familierett etter uavhengigheten på I950tallet. Etter 1990 karakteriseres endringene av mobilisering av ulike samfunnsgrupper, og av sosiale medier som påvirker debatten og innholdet i lovendringene. ${ }^{9}$ Et annet kjennetegn ved reformene, er betoningen av sivile rettigheter som for eksempel likhet for loven. Tidligere var det politiske rettigheter (stemmerett og representasjon) samt økonomiske rettigheter (arbeid, helse, pensjon og utdanning) som ble styrket.

I Egypt ble khul'-prinsippet innført (Lov no. I) i 2000 etter en opphetet offentlig debatt. Lovendringen ga kvinner en selvstendig rett til skilsmisse uten å måtte reise sak i retten mot å gi avkall på rettigheter til økonomisk underhold. Kvinnesaksgrupper hadde jobbet $\mathrm{i}$ over ti år for å styrke kvinners rettigheter innen ekteskap før kvinnelige medlemmer av det statsbærende partiet, Det nasjonale demokratiske parti (NDP), sendte et forslag til justisministeren i I998. Lovforslaget møtte motstand, også blant NDP-representanter: kun én kvinnelig NDP parlamentariker overvar avstemningen der khul'-prinsippet ble vedtatt, mens forslaget om å sikre kvinners rett til bevegelsesfrihet ble forkastet. ${ }^{\text {10 }}$ Fire år senere, i 2004 , ble familiedomstoler etablert sammen med et statlig organ som samordner skilte menns økonomiske fordringer overfor koner og barn (tilsvarende norske Bidragsfogden, men finansiert av en privat bank). Samme år fikk egyptiske kvinner betinget rett til å overføre sitt statsborgerskap til barna.

I Marokko begynte arbeidet med å styrke kvinners posisjon i I998, altså to år før Egypt. En ny og mer politisk sammensatt regjering 
(med medlemmer av det tidligere forbudte Kommunistpartiet) presenterte en omfattende utviklingsplan med hovedvekt på innlemming av kvinner i samfunnsutviklingen. Planen ble motarbeidet av det moderate islamistiske partiet Party of Justice and Development (PJD) også det en historisk nykommer i parlamentet - i samarbeid med konservative og salafistiske grupper." Motstanden hindret ikke kong Mohammed VI å nedsette en I6-medlemmers ekspertkomité i april 200I for å foreslå endringer i familieretten (kjent som mudawwana). Komiteen fikk i mandat å anvende ijtihad, det vil si å foreta en selvstendig fortolkning av religiøs tekst, slik at forslag til lovendringer var i tråd med utviklingsplanen fra I998. I 2004 ble komiteens forslag vedtatt enstemmig i parlamentet. Endringene sikret kvinners selvstendige rett til skilsmisse ved å avskaffe vergeprinsippet og påbudet om at en gift kvinne skal «adlyde ektemannen»; begrenset polygyni; befestet begge foreldres ansvar for barns oppdragelse; og lovfestet I8-årsgrense for kvinners giftemål. ${ }^{12}$ Tre år senere, i 2007 , fikk marokkanske kvinner en betinget rett til å gi statsborgerskap til egne barn.

I Syria var lovendringene mindre omfattende, men synlige. Etter press fra kvinnegrupper fikk syriske kvinner forlenget foreldrerett over barn ved skilsmisse i 2003 (I3 år for gutter og $\mathrm{I} 5$ år for jenter). Kravet om at moren kan bo i hjemmet i tiden hun har foreldrerett ble forkastet. Tre år senere godkjente parlamentet endringer innen katolsk familierett i Syria: katolske kvinner fikk styrket sine sivile rettigheter innenfor ekteskap, og jenter og gutter skulle arve likt. Disse to endringene innen familieretten var de første siden I975, og skjedde uten nevneverdig dramatikk. ${ }^{13}$ Ved utgangen av 2007 snudde reformvinden. Organisasjonen som kjempet for forlenget foreldrerett ble forbudt, og et lovutkast for endringer av familieretten i salafist-ortodoks retning ble avslørt via internett. Lovutkastet var utarbeidet av Justisministeriet og Ministeriet for religiøse anliggender (awqaf), og ble kraftig motarbeidet av en allianse som bestod av kvinnegrupper, statlige etater som arbeidet med å styrke kvinners rettigheter, samt ledere for religiøse minoriteter. Regjeringen ble presset til å trekke tilbake lovforslaget i juli 2009. Omtrent samtidig vedtok parlamentet å endre artikkel 548 i kriminallovginingen slik at minimumsstraffen for kvinnedrap ble hevet fra grovt regnet to-fire måneder til minimum to år. ${ }^{14}$

I Libanon fremmet president Elias Hrawi en alternativ sekulær familierett i I997. Den skulle være et tillegg til de eksisterende familierettene og åpnet opp for at kvinner og menn fikk likeverdige sivile rettigheter innen ekteskap og skilsmisse. Et overraskende stort antall ministre (22 for og 6 mot) stemte for å sende lovforslaget til parlamentet, mot daværende statsminister Rafik Hariris innsigelser. Han mobiliserte en tverreligiøs allianse av politikere og religiøse overhoder som blokkerte lovforslagets videre saksgang..$^{15}$ kjølvannet av lammelsen av parlamentet har det sivile rettssystemet blitt politisert. Domsavsigelser i religiøse domstoler er blitt overprøvd av sivilretten. I 2006 fikk eksempelvis mødre medhold $\mathrm{i}$ en adopsjons- og en foreldrerettssak etter at de tapte sin sak i religiøse domstoler. Domsavsigelsene skaper presedens der sivillovgivning formet i 2002, som implementerer FNs Barnekonvensjon, underminerer religiøse dommeres avgjørelser i familierettslige anliggender. ${ }^{16}$ Sivilretten ble igjen politisert da en historisk dom i 2009 ga en libanesisk enke og firebarnsmor medhold i saken hun reiste mot staten. Hun krevde at barna - som hadde 
egyptisk far, men som var født og oppvokst i Libanon - skulle få libanesisk statsborgerskap. Kvinneorganisasjoner øynet håp om at saken skulle skape presedens, men avgjørelsen ble anket av staten og trukket tilbake i $2010 .{ }^{17}$

\section{Fra marginalisering til feminisering av krav}

I 2006 påpekte Arab Human Development Report at «[i]n general, personal status law in the Maghreb is more progressive than in the Mashriq», uten å gå inn på hva ulikhetene bunner i. ${ }^{18}$ Det er grunn til å se på ulikhetene mellom maghrib- og mashriq-statene fordi forskjellene avspeiler et markant regionalt skille i kvinners statsborgerskap, og fordi de bunner i trekk ved hver statsmakts egenart.

To adskilte, men gjensidig forsterkende drivkrefter for endring - økonomisk globalisering og transnasjonalt press for å forankre arbeidstaker-, kvinne- og menneskerettigheter i nasjonale rettssystemer - belyser påtrykket for reformer.

\section{I: ØKONOMISK OG POLITISK LIBERALISERING}

Siden slutten av I980-tallet har økonomisk liberalisering og globalisering vært fundert på nyliberalistiske prinsipper som frihandel, økt eksportrettet virksomhet koblet med en reduksjon av offentlige utgifter og avskaffelse av statssubsidierte varer og tjenester. ${ }^{19}$ Det spesielle med økonomisk liberalisering i MøNA sammenlignet med andre regioner $\mathrm{i}$ verden er at den i stor grad har vært statssentrert og preget av tilpasning til nye økonomiske realiteter på måter som opprettholder eksisterende økonomiske, sosiale og politiske strukturer. ${ }^{20}$

En slik tilpasning reflekteres i tidspunktet de fire statene undertegnet FNs Kvinnekonvensjon (CEDAw) fra 1979, og i reservasjonene som samtidig ble gjort for å hegne om de kjønnede delene av statslovgivningen. Reservasjonene er knyttet til likhet i statsborgerskapslovgivningen (art. 9); i ekteskap og skilsmisse (art. I6); bevegelsesfrihet og frihet til å velge bosted (art. I5); og når det gjaldt mellomstatlige tvister (art. 29). Med unntak av Libanon reserverte statene seg fra å avskaffe lover som diskriminerer kvinner (art. 2). Egypt var først ute i september i98I i forlengelse av infitah-politikken der landet åpnet seg mot vestlige markeder; Marokko i juni 1993 etter vidtrekkende privatiseringstiltak og styrking av politiske og økonomiske bånd med Den europeiske union via Euromed-samarbeidet; Libanon i april 1997 med gjenoppbyggingsboomen etter borgerkrigen (I975I990); og Syria i 2003 med «Damaskusvåren» $\mathrm{i}$ etterdønningene av Bashar al-Asads maktovertagelse i 2000 .

CEDAW-reservasjonene ga myndighetene fordelene ved økonomisk liberalisering uten at de forpliktet seg til dyptgripende reformer. Med staters tilslutning til Kvinnekonvensjonen oppsto likevel det Sikkink et al. kaller for «transnasjonalt press». Dette kjennetegnes av en sosialiseringsprosess mellom nasjonale og internasjonale aktører der myndigheter presses til å endre adferd og slutte seg til rettsstatsprinsipper selv om de ikke tror på menneskerettsnormenes gyldighet. ${ }^{21}$ Transnasjonalt press understøttet kvinnegruppers formulering av gamle likestillingskrav $i$ en ny rettighetsorientert språkdrakt. Her spilte reformvennlige religiøse lærde og feministiske muslimske tenkere en sentral rolle i å tolke religiøs tekst inn $\mathrm{i}$ en rettighetsorientert diskurs der menn og kvinner hadde like rettigheter. ${ }^{22}$

Mot slutten av i990-tallet fantes 35 offisielle kvinnesaksgrupper i Marokko, mens det 
før I970 fantes kun fem. Lignende oppsving kan spores i de tre andre statene, selv om særlig egyptiske organisasjoner slet med forbudet mot utenlandsk finansiering etter I999. ${ }^{23}$

\section{II: FEMINISERING AV FATTIGDOM}

Økonomisk globalisering banet veien for krav som ble generert av globaliseringens sosioøkonomiske konsekvenser: skjevere fordeling av goder i samfunnet til fordel for de som står myndighetene nær, større arbeidsledighet, strammere offentlige ytelser, samt tegn til feminisering av fattigdom.

Karshenas og Moghadam påpeker at økning i arbeidsstyrken i MøNA var den høyeste i verden mellom I960 til 2000, og viser at MøNA -kvinners andel av økningen er påfallende høy på 4,7 prosent, mens den er på 2,6 prosent i Latin-Amerika, Sør-Asia, og det sørlige Afrika, og I,I prosent i Øst Asia. ${ }^{24}$ Selv om arabiske kvinners arbeidsdeltagelse er den laveste i verden viser økningen likevel to ting:

i) Flere ble arbeidssøkende i møNA sammenlignet med andre regioner i verden, noe som avspeiles i betydelig økt arbeidsløshet.

ii) Fattigdommen er blitt feminisert, dels fordi lønningene til ufaglært arbeidskraft i privat sektor er presset til et så lavt nivå at kvinner i høyere grad tar de lavest betalte jobbene, og dels fordi flere arbeidsledige menn ikke makter å fullføre sin del av det Kadiyoti kaller «den patriarkalske kontrakten» som forsørgere i familien. ${ }^{25}$ Ifølge henne brytes denne i økonomiske og sosiale kriser, og gir grobunn for endringer ved for eksempel arbeidsløshet og økt fattigdom, når en mann forlater kone og barn, eller ved at en kvinne blir enke, skilt eller forblir ugift. ${ }^{26}$

I mangel på offentlige sosiale sikkerhetssystemer som ivaretar arbeidende kvinners økonomiske rettigheter, har krav om endring i familieretten ikke bare juridisk sivilrettslig gjenklang men også en høyst materiell basis. Moghadam slår sågar fast at «family law is a social policy». ${ }^{27}$ Dette perspektivet inntok også sammenslutningen av kvinnelige arbeidstakerorganisasjon i den arabiske verden, The General Union of Arab Women (GUAw), i 2002, da de satte reformer innen familieretten øverst på dagsordenen..$^{28}$

Generell arbeidsløshet, proletarisering av kvinners arbeidskår samt en økt andel av kvinner i lønnet sektor utenfor jordbruket ser ut til å være av betydning for krav om styrkede sivile rettigheter for kvinner. Her skiller maghrib-statene seg markant ut sammenlignet med mashriq-statene. Tar vi bort Gulfstatene der en stor andel kvinnelige migrantarbeidere beregnes som del av arbeidsstyrken, har maghrib-statene den klart høyeste andelen kvinner med lønnet arbeid utenfor jordbruket i hele den arabiske verden: 25 prosent $\mathrm{i}$ Tunisia, 2I prosent i Marokko og I9 prosent i Egypt, mens Syria og Libanon ligger på henholdsvis I 6 prosent og I4 prosent. ${ }^{29}$ Her er det av betydning at de nordafrikanske statene ikke ansetter migrantkvinner som hushjelper og barnepassere, slik det er utbredt særlig i Libanon og i Gulfstatene. I Nord-Afrika ansetter selv lavlønnede utearbeidende mødre sine egne medborgersøstre, ofte yngre jenter og kvinner fra rurale strøk, som barnepassere og hushjelper. $^{3 \circ}$

\section{Regimets respons}

Ytre og indre drivkrefter for endring er ikke sterkere enn den boltreplassen sittende regimer manøvrer seg innenfor når de foretar politiske kalkyler omkring reformer. Selvik og Stenslie ser på arabiske staters tilpasning til økonomiske endringer som «reformisme», og argumenterer for at reformer innføres for å 
demme opp for et vedvarende legitimitetsunderskudd..$^{31}$ Dette perspektivet forklarer bare til en viss grad regimers interesse i å stå i spissen for reformer. For, hvordan forklare hvilke reformer som innføres, forsømmes eller motarbeides, særlig med tanke på at kvinnevennlige reformer motarbeides i alle stater?

Brand bidrar med mer fruktbare tilnærminger. Hun forbinder reformer med politiske regimers usikkerhet rundt deres styrke, og påpeker at reformer skjer som følge av overveielser om potensielle partnere der hovedmålsettingen er å styrke regimets styresett og dets grep om makten..$^{32}$ Ved reformer kan altså regimet forsøkes styrket uten at legitimiteten nødvendigvis økes. De kvinnevennlige reformene i Nord-Afrika etter 2000 ser ut til å

$\odot \odot \odot$

Ulikhetene mellom maghrib- og mashriq-statene bunner $i$ trekk ved hver statsmakts egenart.

$\odot \odot \odot$

være ledd i slike politiske strategier. Når motstanden mot reformer var sterkere i Syria og Libanon enn i Marokko og Egypt, har det sammenheng med institusjonelle forhold som skiller multireligiøse stater fra stater der islam dominerer.

\section{INSTITUSJONALISERING AV RETTSSYSTEMET}

Institusjonalisering av rettssystemet påvirker det politiske rommet som gis for utøvelse av statsmaktens juridiske myndighet. I dag forvaltes familieretten $i$ arabiske stater på grovt sett to måter: I stater der islam dominer, som Marokko og Egypt, er sharia-baserte prinsipper innbakt $i$ statens familierett og reguleres $i$ domstoler som ble til dels sekularisert og sen- tralisert på I950-tallet. I Egypt har medlemmer av Den koptisk-ortodokse kirke (rundt Io prosent av landets befolkning) og andre kristne småsamfunn egne familielover. Disse utøves imidlertid i sekulære domstoler der dommerne retter seg etter sharia-baserte familierettslige prinsipper.

I de multireligiøse statene Libanon og Syria har religiøse grupper egne familielover og ulike grad av autonomi til å regulere familieretten. I Libanon finnes ingen felles familierett - de I8 offisielt anerkjente religiøse gruppene har autonomi i å forvalte sin egen familierett i I4 ulike domstoler (katolske kirkesamfunn har felles familierett). Syria har én felles familierett kodifisert i I953. Loven gir imidlertid unntak for kristne, jøder og drusere som har egne familielover for ekteskap og skilsmisse, samt domstoler i første og annen rettsinstans (tilsvarende norsk ting- og lagmannsrett). Ankesaker i siste instans behandles i Høyesterett der den syriske shariabaserte familieretten fra I953 er rettskraftig.

I de multireligiøse statene skjedde ingen juridisk sentralisering da statene frigjorde seg fra vestlig dominans; parallelle rettssystemer formet under fransk mandat ble tvert imot konsolidert. ${ }^{33}$ Dette forklarer religiøse lærdes vedvarende maktgrunnlag, og viser at opposisjon mot kvinnevennlige reformer ikke bare er rettet mot endringer innen familieretten. Motstanden bunner også i religiøse overhoders motvilje mot å få sin makt redusert i den juridiske sfæren de ser seg selv som forvaltere av. I Syria gir dette utslag i konservative krefters reformulering av familieretten i mer sunni-ortodoks retning, og frykten hos religiøse minoriteter mot å forrykke maktbalansen som Baath-regimet har staket ut for hver religiøs gruppes autonomi. I Libanon er motstanden mot endringer enda sterkere fordi 
religiøse gruppers autonomi er garantert i konstitusjonens artikkel 9 som gir gruppene myndighet til å regulere egne anliggender. ${ }^{34}$

Der islam er den dominerende religionen, skjedde en institusjonell juridisk sentralisering.

Etter uavhengigheten fra Frankrike i I956 styrket for eksempel den marokkanske monarken sin posisjon som religiøs autoritet (amir al-muminim nedfelt i konstitusjonens artikkel I9) ved å stå i spissen for kodifisering av familieretten langs ortodokse linjer, avskaffe autonome domstoler som forvaltet berbisk sedvanerett, og erstatte religiøse lærde med jurister utdannet ved lovskoler tilknyttet Justisministeriet. ${ }^{35}$ For nåværende kong Mohammed VI var grunnen institusjonelt sett beredt for å gjøre ham i stand til å legitimere reformprosessen innen familierett.

Den egyptiske revolusjonen i I952 førte til en viss sekularisering av det juridiske system i I955 (Lov 462): sivile dommere erstattet religiøse dommere i familierettslige saker, og koptiske domstolers uavhengighet ble avskaffet. Den koptiske kirkes tap av juridisk autoritet utad ble imidlertid veiet opp av styrking i de geistliges myndighet innad. ${ }^{36}$ Pave Shenouda strammet grepet ved å tydeliggjøre en konservativ profil der eksempelvis oppløsning av ekteskap sjeldent ble tillatt. ${ }^{37}$ Dette har blant annet ført til at enkelte koptiske menn har konvertert til islam for å få skilsmisse. Med khul'-loven fikk koptiske kvinner en selvstendig rett til å skille seg, og dermed mulighet til å omgå kirkeloven, uten å måtte konvertere. Ringvirkningene av utvidete sivile rettigheter for egyptiske kvinner forrykket med dette den koptiske kirkens autoritet overfor sine medlemmer, noe som har fort til tiltagende voldelige sammenstøt mellom koptere og muslimer etter 2000 rundt saker som har med konvertering og skilsmisse, det vil si saker der enkeltindividers egne valg om å inngå ekteskap og skilsmisse ikke samsvarer med den koptiske familieretten. Kaiser påpeker at kontroversen omkring koptisk familierett «underscores the tension between collective and individual notions of religious freedom and offers an opportunity for the state to advance the civil liberties of all Egyptian citizens.» ${ }^{38}$

Den egyptiske staten står med andre ord overfor en skjør og vanskelig balansegang når og hvis statsmakten søker å styrke enkeltindividers sivile rettigheter i møte med andre menneskerettsprinsipper som hegner om religiøse gruppers kollektive rett til å forvalte egen familielovgivning. ${ }^{39}$

\section{REGIMERS POLITISKE PRIORITERINGER}

Både i Egypt og Marokko var reformer etter årtusenskiftet ledd i å demme opp for islamistisk opposisjon ved hjelp av statsfeministiske tilslag som traff kvinner som potensielle støttespillere. I Marokko manifesterte reformen den islamistiske opposisjonens splittelse i en moderat og en radikal front. Mens den moderate grenen med PJD-parlamentarikerne i spissen stemte for mudawwana-reformen etter langvarige protester, har Brorskapet for rettferd og veldedighet (jamaat al-adl walihsan) utviklet seg til en ekstraparlamentarisk radikal islamistisk gruppe. Når en lignende splid ikke skjedde i Egypt, har det sammenheng med Mubarak-regimets langvarige ekskludering av moderate så vel som radikale islamister fra politisk deltagelse. I begge stater hadde reformene som mål å styrke alliansen med kvinne- og menneskerettsgrupper.

Figur 1: Faktorer som påvirker reform i familielovgivningen i Marokko, Egypt, Syria og Libanon 1980-2010 


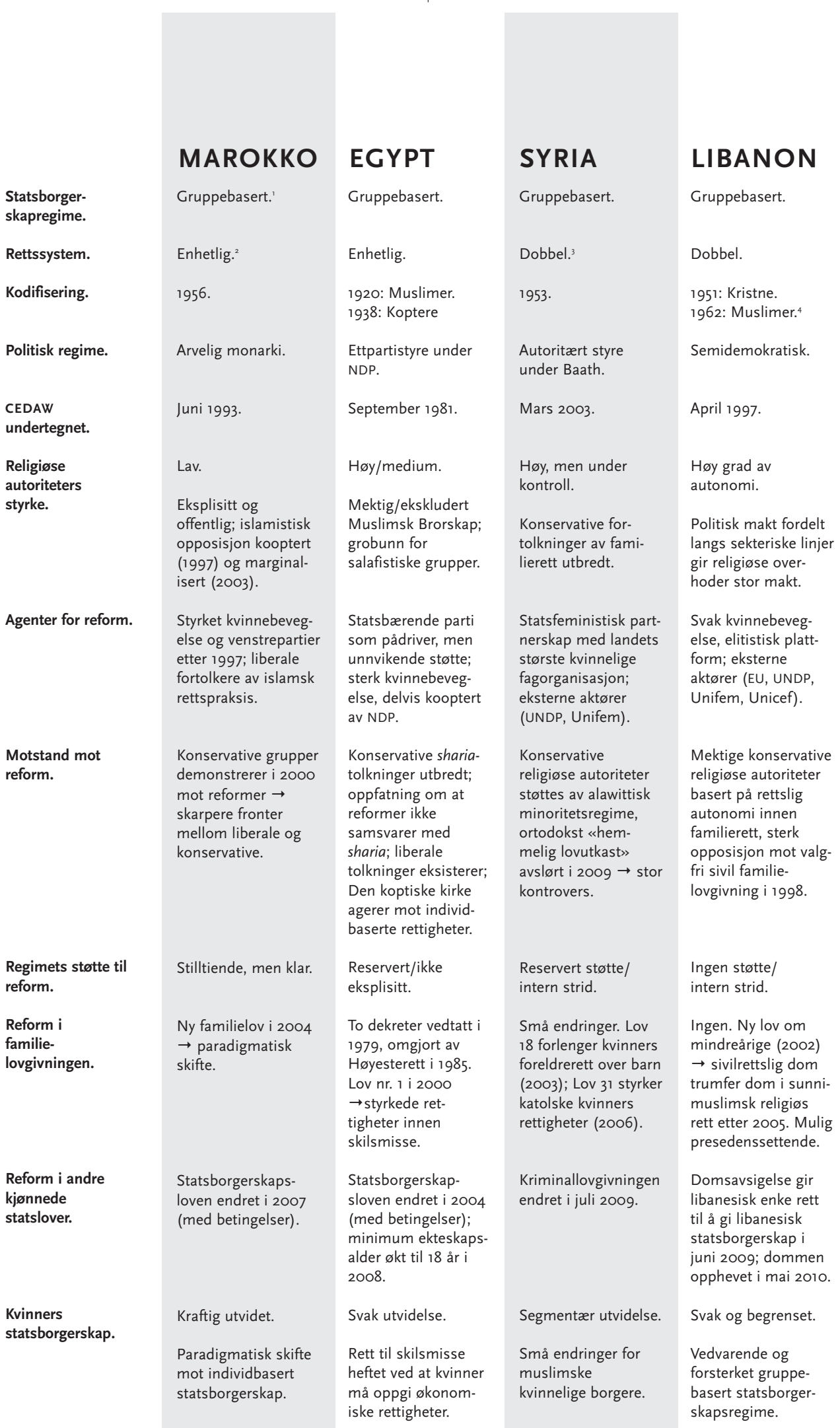


Mudawwana-reformen i Marokko i 2004 hvilte imidlertid på en betraktelig bredere og fastere basis enn khul'-reformen i Egypt i 2000. Et sentralt element her er det marokkanske regimets forsiktige inkludering av islamistiske krefter i det politiske spillet siden I997, og det egyptiske regimets ekskludering av Det muslimske brorskap som legitim politisk gruppering siden I970-tallet.

I Syria og Libanon er makthaveres respons på krav om endringer preget av prioriteringer som bygger på alliansemønstre mellom religiøse og politiske overhoder. I begge stater finner vi utslag av en konservativ byttehandel hvor kvinners sivile rettigheter inngår $i$ et patriarkalsk kompromiss som opprettholder og balanserer eksisterende gruppers maktgrunnlag. ${ }^{40}$ I Syria var motstanden mot reformer i familieretten polarisert og preget av

\section{$\odot \odot \odot$}

Styrking av kvinners statsborgerskap i form av utvidete sivile rettigheter er mer enn et «kvinnespørsmål».

$$
\odot \odot \odot
$$

Asad-regimets Janus-politikk: på den ene siden støtte til grupper som søker å utvide kvinners rettigheter i pakt med Baath-partiets sekulære ideologi, på den andre siden legitimering av arbeidet innen Justisministeriet og awqaf som styrket en religiøst fundert og kjønnet statslovgivning. Resultatet var små endringer som utvidet kvinners sivile rettigheter, men som ikke rørte ved hovedtrekkene i det kjønnede statsborgerskapet.

I Libanon var motstanden sterkere enn i Syria fordi endringene rører ved selve fundamentet som statsmakten hviler på. En av det politiske regimets pilarer er grunnlagt på religiøse gruppers autonomi, noe som nører opp om og konsoliderer et symbiotisk forhold mellom politikere og konservative religiøse overhoder. En sekulær familierett rokker ved prinsippet om borgerens religiøst-baserte medlemskap i staten der politisk representasjon og fordeling av byråkratiske posisjoner gjenspeiler en stram, numerisk 50-50 likevekt mellom borgere av muslimsk og kristen bakgrunn. Utvidelse av kvinners så vel som alle borgeres ikke-religionsbaserte sivile rettigheter, griper inn i selve statsforfatningen og ble derfor motarbeidet kraftig av religiøse og politiske overhoder som ser sine interesser truet.

\section{Kvinners sivile rettigheter}

Kvinners betingete og begrensete medlemskap i de fleste arabiske stater kompliserer deres politiske deltagelse. Kvinners ufullkomne statsborgerskap gjør etterdønningene av den arabiske oppvåkningen våren $201 \mathrm{I}$ potensielt sett mindre fruktbar for kvinnelige borgere hvis deltagelsesspørsmål som frie politiske valg, dannelse av flerpartisystemer og oppbygging av en fri presse overskygger eller tilsidesetter medlemskapsspørsmål som omfatter utvidelse og styrking av kvinners sivile rettigheter, særlig innen familieretten.

Utarbeidelse av en ny konstitusjon eller valglov i Egypt vil for eksempel ikke styrke kvinners sivile rettigheter all den tid familieretten betinger disse. Der Egypt har muligheter til å vise vei, er ved å stake ut en juridisk og politisk balansegang hvor grupperettigheter enten disse baseres på kristne eller muslimske religiøse forordninger - ikke trumfer individuelle borgerrettigheter.

Den historiske erfaringen siden arabiske staters selvstendighet tilsier at det er i styrking av individbaserte sivile rettigheter at kvinner har fått utvidet sitt statsborgerskap. Det siste 
tiårets press for å endre kjønnede statslover viser at endringer innen familieretten åpnet opp for reformer i andre deler av statslovgivningen: ved styrking av sivile rettigheter innen familieretten fikk eksempelvis først tunisiske (I956), dernest egyptiske (2000) og deretter marokkanske kvinner (2004) utvidete rettigheter innen statsborgerskaps- og kriminallovgivningen.

Endringer innen familieretten det siste tiåret tydeliggjør et markant regionalt skille mellom mashriq og maghrib når det gjelder utvidelse i kvinners sivile rettigheter. Tre konkluderende refleksjoner avslutningsvis kan, for det første, være at sentraliseringen av det juridiske system i forhold til forvaltning av familieretten er av betydning for utvidete sivile rettigheter for kvinner. Denne sentraliseringen er mindre problematisk i stater der islam dominerer, men - slik tilfellet Egypt viser - byr på sammenlignbare grunnlagsproblemer omkring individ- og gruppebaserte rettigheter vi finner i multireligiøse stater.

For det andre, støtte fra det styrende politiske regimet i samarbeid med sekulært orienterte grupper (venstrepartier, menneskerettsog kvinnegrupper) er avgjørende for å få i havn kvinnevennlige reformer i parlamentet. ${ }^{41}$ I maghrib-statene har transnasjonalt press åpnet opp for slike allianser på tvers av type politisk regime. I iveren etter å diskreditere NDPS politikk i Egypt er det ikke usannsynlig at politiske partier vil opprettholde en konservativ profil og unnlate å fronte saker som rører ved kjønnede statslover for å tekkes velgere. Slike konservative politiske allianser finner vi i Polen, Nicaragua og Chile, der den katolske kirken er en betydelig støttespiller for konservative partier. Der har utvidelse i politisk deltagelse ført til innskrenkinger i kvinners sivile rettigheter i forhold til abort. Erfar- ingen fra Irak viser likeledes hvordan delegering av juridisk myndighet over familieretten til religiøse overhoder ble et forhandlingskort umiddelbart etter Saddam Husseins fall da Resolusjon 137 ble foreslått av Iraks overgangsregjering i desember $2003 \cdot{ }^{42}$

For det tredje, styrking av kvinners statsborgerskap i form av utvidete sivile rettigheter er mer enn "kvinnespørsmål". Det innebærer en omfordeling av makt i samfunnet og sentralisering av juridisk myndighet, inklusivt religiøs autoritet, på måter som endrer premissene for utøvelse av statsmakten. Kampen om endringer innen det kjønnede statsborgerskapet er en kamp for å innlemme arabiske kvinner som fullverdige medlemmer av statens demos. Denne kampen er uløselig knyttet til utviklingen av arabiske stater i mer demokratisk retning. En rekke reformer i maghribstatene har beredt grunnen for en bredere innlemming av «massene» - de sivilrettslig marginaliserte kvinner - som fullverdige borgere av staten. ${ }^{43}$ Endringer i levantinske stater er mindre sannsynlig i overskuelig framtid fordi den politiserende kjøpslåingen av kvinners sivile rettigheter er en del av politiske prioriteringer mellom religiøse og politiske overhoder som ser egne interesser truet ved dyptgripende endringer.

$$
\cdot f \cdot
$$

I Joseph, Suad: Gender and Citizenship in the Middle East. Syracuse, N.Y.: Syracuse University Press, 2000; Moghadam, Valentine M.: Modernizing Women: Gender and Social Change in the Middle East. Boulder, Colo.: Lynne Rienner, 2003

2 The Global Gender Gap Report 20I0, World Economic Forum, http://www3.weforum.org/docs/WEF_Gender Gap_Report_20I0.pdf, (20.08.20II). For informative landstudier, se Women's Rights in the Middle East and North Africa 20I0, Freedom House. http://freedom house.org/template.cfm? page $=383 \&$ report $=86$ (20.08.20II) 
3 Midtøsten og Nord-Afrika - MøNA - har en vestlig del (kalt maghrib på arabisk) som omfatter statene i NordAfrika, og en østlig del (kalt mashriq på arabisk) som omfatter arabiske stater øst for Suez-kanalen. Egypt ansees i denne artikkelen å høre geografisk til i NordAfrika, og er dermed en del av maghrib, selv om arabisk språkbruk tradisjonelt sett begrenser begrepsbruken til Marokko, Tunisia og Algerie. Begrepet 'Levanten' brukes her som betegnelse for området som også går under navnet 'Den grønne halvmåne', og som omfatter statene Libanon, Syria, Jordan og Irak.

4 Forbindelsen mellom statsborgerskap og utviklingen av rettigheter i vestlige demokratier knyttes gjerne til den britiske sosiologen T.H. Marshall. Marshall, T.H.: Citizenship and Social Class and Other Essays. Cambridge: Cambridge University Press, I950. Feministiske forskere har kritisert og supplert denne inndelingen med analyser som viser hvordan kvinners og menns statsborgerskap forløper seg på ulikt vis. Se Hernes, Helga: "Kvinners medborgerskap i den skandinaviske velferdsstaten," i Virker Velferdsstaten?, red. Hvinden, Bjørn, Ann-Helen Bay, Charlotte Koren. Kristiansand: Høyskoleforlaget, 200I; Pateman, Carole: Democratization and Citizenship in the 199os: the Legacy of T.H. Marshall, vol. 96:I7, Rapport. Oslo: Institutt for samfunnsforskning, I996.

5 Begrepet 'polygyni' markerer at det er mannen som har flere koner, mens 'polygami' betegner mangegifte der kvinner og menn har flere partnere.

6 Sfeir, George N.: "The Place of Islamic Law in Modern Arab Legal Systems: A Brief for Researchers and Reference Librarians“, i 28 Int'l J. Legal Info. II7, 2000.

7 Joseph, Gender and Citizenship in the Middle East, 20.

8 Moors, Annelies: "Public Debates on Family Law Reform - Participants, Positions, and Style of Argumentation in the I990s", i Islamic Law and Society, vol. IO, no. I, 2003.

9 Welchman, Lynn: Women and Muslim Family Laws in Arab States: A Comparative Overview of Textual Development and Advocacy. Amsterdam: Amsterdam University Press, 2007, S. I2-I3, 42-43.

Io Tucker, Judith E.: Women, Family and Gender in Islamic Law. Cambridge: Cambridge Universtiy Press, 2008 , I28; Fawzy, Essam: "Law no. I of 2000: A New Personal Status Law and a Limited Step on the Path to Reform" i Women's Rights and Islamic Family Law, red. Lynn Welchman. London: Zed Press, 2004.

II Busken, Léon: "Recent Debates on Family Law Reform in Morocco: Islamic Law as Politics in an Emerging Public Sphere" i Islamic Law \& Society vol. o, no. I, 2003, s. 84-I03.

I2 Se http://www.hrea.org/moudawana.html for den engelske teksten av mudawwana, (26.03.20II)

I3 Maktabi, Rania: "Gender, family law and citizenship in Syria”, i Citizenship Studies, vol. I4, no. 5, 2010.
I4 Maktabi, Rania: "Female Citizenship in Syria: Framing the 2009 Controversy over the Draft Laws on Personal Status" i kommende bok om Syrias politiske økonomi redigert av Raymond Hinnebusch og Tina Zintl.

I5 Zuhur, Sherifa: "Empowering women or dislodging sectarianism? Civil marriage in Lebanon" i Yale Journal of Law and Feminism, vol. I4, no. I, 2002.

I6 Zalzal, Marie Rose, Ghada Ibrahim, Nada Khalifa: al'unf al-qanuni didd al-mar'a fi lubnan. Qawanin alahwal ash-shakhsiyya wal-'uqubat. Beirut: Dar al-Farabi, 2008 , s. 53 .

I7 Musawi, Ali: "mahkamat al.bidaya tanqalib 'a vla al-ijti hadat al-qada'iypa: man' awlad al-muwatina almuazawwija min ajnabi al-jinsiyya al-lubnaniyya", i AsSafir, Beirut, I7. juni 2009; Musawi, Ali: “isti'nafan hay'at al-qadaya wal-niyaba mardudan li-intifa' al-sifa wal-maslaha", i As-Safir, Beirut, I9. mai 2010.

I8 “Towards the Rise of Women in the Arab World", Arab Human Development Report 2005, United Nations Development Program. Amman: National Press, 2006, S.I9.

I9 Woods, Ngaire og Andrew Hurrell: Inequality, Globalization, and World Politics. Oxford: Oxford University Press,I999.

20 Richards, Alan og John Waterbury: A Political Economy of the Middle East. Boulder, Colo.: Westview Press, 2008, s. 2II-I8, 60-6.

2I Sikkink, Kathryn, Thomas Risse og Steve C. Ropp, red.: The Power of Human Rights: International Norms and Domestic Change. Cambridge: Cambridge University Press, I999, S. IO-I4.

22 Vogt, Kari, Lena Larsen og Christian Moe, red.: New Directions in Islamic Thought: Exploring Reform and Muslim Tradition. London: Tauris, 2009. Ziba MirHosseini, "Muslim Women's Quest for Equality: Between Islamic Law and Feminism", i Critical Inquiry 32, 2006.

23 Skalli, Loubna H: "Communication and Democratization in Marocco" i From Patriarchy to Empowerment, red., Valentine M. Moghadam. Syracuse, New York: Syracuse University Press, 2007, s. I23; Hicks, Neil, "Transnational Human Rights Networks and Human Rights in Egypt", i Human Rights in the Arab World, red. Anthony Tirado and Amr Hamzawy Chase. Philadelfia: University of Pennsylvania Press, 2006, s. $82-83$.

24 Karshenas, Massoud og Valentine M. Moghadam, red.: Social Policy in the Middle East: Economic, Political, and Gender Dynamics. Basingstoke: Palgrave Macmillan, 2006 , s. I3.

25 Moghadam, Valentine M.: "States and Social Rights: Women's Economic Citizenship in the Maghreb", i Middle East Law and Governance vol. 2, no. 2, 2010, s. 228-30. 
26 Kandiyoti, Deniz: "Islam and Patriarchy: A Comparative Perspective", i Feminist Approaches to Theory and Methodology, red. Christina Gilmartin, Sharlene HesseBiber, Robin Lydenberg. New York / Oxford: Oxford University Press, I999, s. 228-3I.

27 Karshenas og Moghadam, op. cit., s. 222.

28 Intervju med Sumayya al-Ghanim, leder av juridisk avdeling for Syrias største kvinneorganisasjon General Women's Union, som forklarte at GUAWs prinsipperklæring var hovedgrunnen til at Syria fulgte opp med å fokusere på forslag til endringer av Syrias familierett, Damaskus, 23. november 2006.

29 Andelen kvinner med lønnet arbeid utenfor jordbruket vektlegges særskilt. I den arabiske verden er denne andelen spesielt lav - under 30 prosent. Se Global Gender Gap Report 2010. For landindikatorer, se Key Indicators of the Labour Market, International Labour Organization, http://kilm.ilo.org/KILMnetBeta/ default2.asp (23. august 20II)

30 Moghadam, op. cit., I99, 205.

3I Selvik, Kjetil og Stig Stenslie: Stabilitetens pris: stat og politikk i Midtøsten. Bergen: Fagbokforlaget, 2007, s. 106-07.

32 Brand, Laurie A.: Women, the State, and Political Liberalization: Middle Eastern and North African Experiences. New York: Columbia University Press, I998, s. 3-6.

33 Méouchy, Nadine: "La Réforme des Jurisdictions Religieuses en Syrie et au Liban (I92I-I939): Raisons de la Puissance Mandataire et Raisons des Communautés", i Le Choc Colonial et l'Islam: Les Politiques Religieuses des Puissances Colonials en Terres d'Islam, red. Pierre-Jean Luizard. Paris: La Découverte, 2006.

34 Artikkel 9 i den libanesiske konstitusjonen av 1926 slår fast at "[t]he State [...] shall respect all religions and creeds and guarantees, under its protection, the free exercise of all religious rites provided that public order is not disturbed. It also guarantees that the personal status and religious interests of the population, to whatever religious sect they belong, is respected." (http://www.nowlebanon.com/Library/Files/English Documentation/Official\%20Documents/Lebanese \%20Constitution.pdf), (05.03.20II)

35 Charrad, Mounira: States and Women's Rights: the Making of Postcolonial Tunisia, Algeria, and Morocco. Berkeley: University of California Press, 200I, s. I6I62, 67; Mir-Hosseini, Ziba: Marriage on Trial: Islamic Family Law in Iran and Morocco. London: I.B. Tauris, 2000, s. 26-27.

36 Tadros, Mariz: "Vicissitudes in the Entente between the Coptic Orthodox Church and the State in Egypt (I952-2007)", i International Journal of Middle East Studies, vol. 4I, no. 2, 2009, s. 269-70.

37 Guindy, Adel: “Family Status Issues among Egypt's Copts: A Brief Overview", i Middle East Review of International Affairs, vo. II, no. 3, 2007.
38 Kaiser, Katherine: "Coptic Marriage Law and the Church-State Divide in Egypt", i The Review of Faith Q International Affairs, 2010, http://rfiaonline.org/extras/ articles /678-coptic-marriage-law-and-the-church-statedivide-in-egypt (I5.03.20II)

39 Scolnicov, Anat: The Right to Religious Freedom in International Law: Between Group Rights and Individual Rights. London and New York: Routledge, 20II.

40 Kandiyoti, Deniz: "Bargaining with Patriarchy", i Gender and Society, vol. 2, no. 3, I988, s. 286.

4I Clark, Janine A. og Amy E. Young: "Islamism and Family Law Reform in Morocco and Jordan", i Mediterranean Politics, vol. I3, no. 3, 2008, s. 34I-44.

42 "Women and the Law in Iraq", Institute for International Law and Human Rights, December 2010, iilhr.org/documents/womenandlawiniraqEN.pdf. (25.08.20II)

43 'Massene' er et lånt uttrykk fra nasjons- og statsbyggingsteoretikere som så på arbeidsklassens innlemmelse i det politiske fellesskap som en sentral del av demokratiseringen av vestlige liberale stater. Bendix, Reinhard: Nation-Building and Citizenship: Studies of Our Changing Social Order. Berkeley, Calif.: University of California Press, I977, s. 89-91.

NOTER TIL FIGUR I:

I 'Gruppebasert statsborgerskap’ antyder at: a) statslovgivningen er basert på borgeres medlemskap i religiøse og/eller etniske grupper; og b) statslovgivning lovfester mannlig vergeskap over kvinnelige borgere i familieretten. Mer om gruppe- og individbasert statsborgerskap i Rania Maktabi, kommende Ph.D., Institutt for statsvitenskap, Universitetet i Oslo.

2 Sentralisert juridisk system

3 Sivilrettslige domstoler eksisterer sammen med religiøse domstoler

4 De I8 religiøse konfesjonene har egne familielover. Datoen viser etablering av en organisatorisk ramme rundt familieretten. 